\title{
Re-interpreting Deuteronomy to Empower Women (of South Africa)
}

\author{
Doniwen Pietersen (University of Pretoria)
}

\begin{abstract}
The patriarchal discourse in the Deuteronomic Code creates the need for its re-interpretation from a feminist perspective. This is in aid of understanding the subordination of women viewed from the following perspectives: their roles, images and the limited contributions of women in the ancient world. The reading also includes some remarks on the patrilineal and patriarchal organisation of the Israelite society and its family-centred economy - with special reference to the Covenant Code because of its similarity to Deuteronomy. This article describes how reformers of the Code formed a social structure which they made effective by linking disempowerment of women with other poverty alleviation laws.
\end{abstract}

KEYWORDS: Deuteronomic Code, Socio-economic, Covenant Code, Social-scientific interpretation, Gender inequality

\section{A INTRODUCTION ${ }^{1}$}

This article explores possible ways of re-interpreting (inner-biblical) the Deuteronomistic Code (including to some extent the Covenant Code because of their inter-relationship) in order to show how Israelite society and its familycentred economy disempowered women. To this end,

We [need to] understand the central role of religion in many women's lives, and we suggest that a new theology taking clearer account of women may be productive in understanding the central role of faith in people's lives [particularly in women's lives]. ${ }^{2}$

* Submitted: 21/09/2020; peer-reviewed: 05/06/2021; accepted: 11/11/2021. Doniwen Pietersen, "Re-interpreting" the Deuteronomic Code to Empower Women (of South Africa)," Old Testament Essays 34 no. 3 (2021): 768 - 788. DOI: https://doi.org/10.17159/2312-3621/2021/v34n3a7.

1 This article is part of the dissemination of a $\mathrm{PhD}$ dissertation entitled, "Disempowerment of and Violence against Women: Old Testament Perspectives," under the supervision of Prof. D.J. Human, Department of Old Testament and Hebrew Scriptures, Faculty of Theology and Religion, University of Pretoria.

2 Juliana L. Claassens, Shaikh Sa'diyya and Leslie Swartz, "Engaging Disability and Religion in the Global South," in The Palgrave Handbook of Disability and Citizenship in the Global South (Cham: Palgrave Macmillan, 2019), 147-164. 
A re-interpretation of Deuteronomistic laws (theology) to empower women contributes to the creation of a sense of equality in all spheres of spirituality and the lived experiences of women, which includes covering the spiritual and socioeconomic conditions such that values represented in these laws enable and do not disempower them.

It is important to highlight that the context in which the Deuteronomistic laws originated developed and were applied in highly hierarchical ways across all spheres of society where there was no equality, much less gender equality, ${ }^{3}$ as seen in the 21 st century. This point is acknowledged throughout this article. However, the aim is to critique and re-appropriate the laws of such a disempowered society and culture for the benefit of the contemporary reader. Bosman asserts that in the context of the renewal of ancient laws, ${ }^{4}$ a "second law"5 was necessary. This work supports this assertion within the framework of how human beings evolved and civilisations became more complex in the $21 \mathrm{st}$ century, particularly, with regard to the abuse and negative treatment of women.

Therefore, in order to theologise towards a more inclusive 21st century society where women should be empowered, we ought also to recognise that the two worlds under consideration here are actually far apart in the way value systems were set up, particularly, in the treatment of women. However, this article contends that in the critical exploration of the Deuteronomistic Code (and briefly the Covenant Code) that also aims to re-interpret the text for women as contemporary readers, these laws may show that the aforementioned worlds (ancient Israelite and South African) may actually be much closer than assumed especially in relation to the patriarchal disempowerment of women. In the unfolding of this study, a feminist reading will become clear.

3 Cf. Victor H. Matthews and Don C. Benjamin, Social World of Ancient Israel: 1250-587 BCE (Peabody: Hendrickson, 1993), 50; Mark Sneed, "Social Scientific Approach to the Hebrew Bible," Religion Compass 2/3(2008): 207.

4 See Hendrik J.L. Bosman, "Such a Thing Is not Done in Israel: The Judicial System of Ancient Israel," Plutocrats and Paupers. Wealth and Poverty in the Old Testament (ed. H.L. Bosman, I.G.P. Gous and I.J.J. Spangenberg; Pretoria: J.L. van Schaik, 1996): 190-205.

5 Cf. The Greek appellation of the book, "To Deuteronomion (hence, Latin Deuteronomium)" and the Hebrew appellation, "Mishneh Torah" (based on Deut. 17:18; Josh 8:32) mean repeated law or second law and allude to the fact that Deuteronomy is a revised repetition of a large part of the law and history of the Tetrateuch (the first four books); compare Nahmanides to Deut 1:1 and in Ezra to Deut 1:5. See Moshe Weinfeld, Deuteronomy 1-11 (The Anchor Bible Volume 5; New York: Doubleday, 1995), 1. 


\section{B EXODUS, DEUTERONOMY AND DISEMPOWERMENT OF WOMEN}

This discussion takes as its point of departure the remark by Frank Crüsermann on the Pentateuch that, "the Pentateuch, the new entity, did not come into being as a law book simply by using older material, but rather by juxtaposing totally unbalanced, even contradictory documents from different epochs. ${ }^{.6} \mathrm{He}$ argues that "the Covenant Code, the Deuteronomic/Deuteronomistic Code and the Holiness Code, all found in the Pentateuch, could not have been intended as simple expansions of their respective older forms, they could only be replacements." ${ }^{77}$ However, before comparing the law codes, it is important to make a few preliminary remarks about the context(s) of the Deuteronomic/Deuteronomistic Code which is the broader context of the text on which this article is based and which promotes the disempowerment of women. ${ }^{8}$

Deuteronomy comprises thirty-four chapters. Using a broader demarcation, the book is divided into "historical prologue 1:1-4:43; the Law 4: 44-28:68, blessings and curses 29:1-30:20 and a conclusion 31:1-34:12." focus of this article is the Law section, Deut 4: 44-28:68, and specifically, Chapters 12-26, which are referred to as the Deuteronomic/Deuteronomistic Code. Parks states that, "This Deuteronomic/Deuteronomistic Code is compared with the other two codes in the Pentateuch: The Covenant Code and the Holiness Code. The comparison shows that they are different codes that also highlight the negative plight of women." 10

Park also adds that this may have originated in the royal court with its schools of scribes and jurists. ${ }^{11}$

The codes reflect different "centres of power" which might have similar but not necessarily the same interests. Jean-Louis Ska explains that, "on the one hand, many of the legislative and narrative texts are quite similar and, on the

6 See Frank Crüsermann, The Torah: Theology and Social History of Old Testament Law (Minneapolis: Fortress Press, 1996), 9.

7 Crüsermann, The Torah, 8.

8 David P. Wright, “'She Shall not Go Free as Male Slaves Do': Developing Views about Slavery and Gender in the Laws of the Hebrew Bible," in Beyond Slavery (ed. Bernadette Brooten; New York: Palgrave Macmillan, 2010), 126.

9 Cf. Doniwen Pietersen and Dirk J. Human, "YHWH's Mouthpiece to the Exiles," Stellenbosch Theological Journal 7/1 (2021): 2.

10 Cf. Esther H. Park, "Women in Exodus and Asian Immigrant Women: Asian Female Immigrants' Bible Reading Strategy on Exodus 1-4," T\&T Clark Handbook of Asian American Biblical Hermeneutics (2019): 222.

11 Crüsermann, The Torah, 166. 
other hand, they contain undeniable differences." 12 These differences speak to how women are perceived. Therefore, in examining the disempowerment of women, Wittenberg concludes that "the issue cannot be resolved only by a biblical approach" but that a combination of approaches is needed including the two employed in this research, which are the social scientific and theologicalethical approaches. As Raben states, "The point is that in the Bible one finds more than one perspective on the same issue, so a perspective of a particular book remains the perspective of that book and not of the whole Hebrew Bible."13

In the remainder of this article, arguments will be presented to show that the issue of the disempowerment of women can better be understood using the social-scientific ${ }^{14}$ and theological-ethical approaches to read Deuteronomy. This article, then, considers both deconstruction and reconstruction in order to reinterpret the Deuteronomistic laws. The methodology of this article is supported by Meyers, who employs a social scientific approach to read the Bible with regard to the issue of women's disempowerment and other related topics such as patriarchy. She notes that:

Since the late nineteenth century, if not before, the term "patriarchy" has been invoked by those seeking to understand the cultural context of biblical texts. And more recently, it frequently appears in feminist discourse that examines and often critiques the presentation of female figures in narratives and other texts in the Hebrew Bible. ${ }^{15}$

The present contribution probes the consequences of patriarchy in Israelite society as mentioned above in order to argue for a re-interpretation that would empowerment women in the 21 st century context, especially in South Africa where the Bill of Human Rights and South Africa's Constitution are upheld as delineating an equal and transformative society.

The perspective of Deuteronomy's patriarchal society seems to be more compatible with the empowerment of women that is promoted by the societal structure that is currently in place in South Africa ${ }^{16}$. To demonstrate this claim,

12 Jean-Louis Ska, Introduction to Reading the Pentateuch (Winona Lake: Eisenbrauns, 2006), 40.

13 Cf. Volker Rabens, “The Bible and Ethics: Pathways for Dialogue," In die Skriflig 51/3 (2017): 5.

14 Philip F. Esler, Ancient Israel: The Old Testament in Its Social Context (Fortress Press, 2006), 14.

15 See Carol L. Meyers, "Was Ancient Israel a Patriarchal Society?" Journal of Biblical Literature 133/1 (2014): 8.

${ }^{16}$ See South Africa's Bill of Rights, it is very much inclined to seek the empowerment of women. 
an example may be made of the issue of slaves. ${ }^{17}$ In the Covenant Code, Exod 21:7 reads: "and if a man sells his daughter as a slave woman, she will not go out as male slaves go out." The verse shows that the release of "male and female" slaves would not be on same terms. Similarly, the Deuteronomic/Deuteronomistic Code states in Deut 15:12 and 17 that, "if your relative who is a Hebrew man or a Hebrew woman is sold to you, and he or she has served you six years, then in the seventh year you shall send that person out free... And to your female slave you shall not do the same." Here, the release of "male and female" slaves is also not based on the same terms. This suggests a disempowerment cycle in which women are treated unfairly, as though they are second-class citizens.

\section{DEUTERONOMIC/DEUTERONOMISTIC HISTORICAL SETTING}

\section{CODE}

According to Otto, the book of Deuteronomy was written during the late postexilic period, from around $539 \mathrm{BCE}$, a time when a great deal of revision of the text took place. ${ }^{18}$ Otto's view appears convincing and it is informed by his theory about the re-interpretation of past centuries, Wirkungsgeschichte. Otto applies this theory to Moses, who is seen as re-interpreting the book of Exodus. He asserts that Moses' exegesis was re-interpreted in new contexts, new periods and new situations. New permutations and meanings were discovered over time as the literary Moses interacted with his context. ${ }^{19}$ An example of this is the Mount Sinai scene where laws were given to Israel - the laws in fact were written only about 40 years later on the plains of Moab, which is made clear by the change of situation, place and period. New meanings had to be created of how the laws developed with the people..$^{20}$ Otto's view disagrees with Noth's theory that the Deuteronomistic History includes Deuteronomy right through to the books of Kings. However, to justify Noth's theory, one would need to detach Deuteronomy from the Pentateuch. According to Otto, this would mean that Noth would need to argue away the re-interpretation of the Sinai Torah, which is rather difficult to do. ${ }^{21}$ Therefore, Deuteronomic/Deuteronomistic History

17 Cf. In the ancient Near Eastern context, women and slaves had different social statuses from men and fulfilled different roles. However, the negative treatment of both of these groups are similar.

18 See Eckhart Otto, Deuteronomium 1-11: Herders theologischer Kommentar zum Alten Testament (Freiburg:Herder, 2012), 3.

19 Jurie Le Roux, "We Are Shaped by Past Interpretations," Verbum et Ecclesia 40/1 (2019): 3 .

20 Eckhart Otto, Das Deuteronomium in Pentateuch und Hexateuch: Studien zur Literaturgeschichte von Pentateuch und Hexateuch im Lichte des Deuteronomiumrahmens (Tubingen: JCB Mohr-Paul Siebeck, 2000), 43-83.

21 Otto, Deuteronomium 1-11, 133-137. 
belongs to the literary history of the Pentateuch and should be treated as such for Deuteronomy to make sense.

Marsman $^{22}$ affirms that Deuteronomic/Deuteronomistic History should be seen as part of the reception of the Pentateuch. ${ }^{23}$ A fuller understanding of the topic of female disempowerment and violence against women will become apparent in the "striking similarities between the Pentateuchal and the Ancient Near Eastern (ANE) texts." Although there are similarities and differences in these texts in relation to how women were treated, one also needs to affirm that "individual cultures of the Ancient Near East were not solitary functioning systems, like islands, but subject to mutual influence." ${ }^{24}$ Van der Toorn ${ }^{25}$ calls this phenomenon a "cultural continuum." This idea is helpful because it sheds light on the societal attitudes towards women in history. ${ }^{26}$

It is agreed that the Deuteronomic/Deuteronomistic Code (Deut 12-26), though widely regarded as the "original" Deuteronomy and the oldest part of the book, is a product of Josiah's reform (a view endorsed by Martin Noth and others). If we agree with this view, the political changes which occurred during that era (649-609 BCE) hold much significance. The law and the reformation had a strong bearing on the weakening and collapse of Assyrian control over Judah. For a century, Assyria ruled over Judah (736/733-630/622 BCE). Assyrian dominance over Judah can be seen from the Syro-Ephramite war (736$733 \mathrm{BCE})$ to Josiah's reforms (622 BCE). By the time Josiah came to the throne, the power of Assyria had declined, which probably was a major reason for

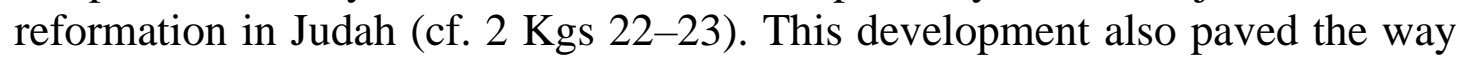
for Judah to control her sister kingdom, Israel. ${ }^{27}$ The destruction of the sanctuary at Bethel and the suppression of its priesthood (2 Kgs 23:15-20) are clear references to this. The rapid decay of the Assyrian empire must have encouraged Josiah to throw off his vassalage and abandon the agreement between him and the Assyrian king. Thus, Josiah took full advantage of the weakness of the Assyrian Empire and established unity in Israel by attaining a separate identity and freedom from external political, social and religious interference. This aspect of unity can be seen in the book of Deuteronomy. In the light of these political

22 See Hennie J. Marsman, Women in Ugarit and Israel: Their Social and Religious Position in the Context of the Ancient Near East (Leiden: Brill, 2003), 33.

23 Eckhart Otto, Religion Past \& Present: Encyclopaedia of Theology and Religion (Leiden: Brill, 2011), 678-688.

24 Walter Brueggemann, Deuteronomy (Nashville: Abingdon Press, 2001), 164.

25 Karen, Van der Toorn, Family Religion in Babylonia, Syria and Israel: Continuity and Change in the Forms of Religious Life (Studies in The History and Culture of the Ancient Near East VII; Leiden: Brill, 1996), 4.

26 See Fanie Snyman, "A Theological Appraisal of the Book of Malachi" OTE 27/2 (2014): 605-606.

27 Bern, U. Schipper, "Egypt and the Kingdom of Judah under Josiah and Jehoiakim," TEL AVIV 37/1 (2010): 200. 
developments, we can better understand the laws of Deuteronomy and human rights (the right to food, equality and self-determination). Unlike other legal codes, the laws of Deuteronomy are highly moralistic and humanitarian. They are concerned with the notion of Israel being a chosen and redeemed nation and with the expectation that human beings should treat each other in the same gracious way that God has treated them. In contrast with other parallel codes, the laws give more importance to the overall cultural development of Israel.

\section{SLAVE LAWS IN DEUTERONOMY AND EXODUS COMPARED}

Deuteronomy 12-26 presents the detailed law of the covenant. It deals with the religious life (unity and purity of Israel's worship, sporadic obligations and institutions), political life (the responsibility of officials of the theocratic state towards their nation and vice versa) and social life (respect of individuals towards each other, particularly in the context of family relationships, humanitarian behaviour, first fruits and tithing). As some of the laws correspond, for instance, with the Decalogue and slavery, it is argued by some scholars that the Deuteronomic/Deuteronomistic Code is a modification of the Exodus Code, while others claim that the Deuteronomic/Deuteronomistic Code harmonises the legislation of the Covenant and Holiness Codes.

\section{Deuteronomy 15:12-18}

The slave law in Deut 15:12-18 is casuistic in style and made up of two sections (vv.12-15a and vv.16-18). Verse 15b forms the centre of the literary unit, emphasising the reason for redeeming an indentured servant. Each of these sections has a law in casuistic form, followed by an exhortation (v.15 and v.18). ${ }^{28}$

The law in Deuteronomy advocates the release of all of Israel's slaves after a period of six years whereas the Exodus law seeks the contrary. Moreover, at the time of release, "the owner must not send them away empty-handed, but must rather provide for them generously." The people should show empathy towards those who have been forced into servitude due to difficult circumstances. ${ }^{29}$ However, in spite of this provision, the slaves are free to remain with their masters for life, which contradicts the law of release in the Covenant Code (Exod 21:7-11).

Deuteronomy 15:12-18 provides for remission for those who have lost their freedom due to debt and poverty, referring to debt slaves rather than foreign slaves. After serving as a slave for six years, the Hebrew man or woman must be freed in the seventh year and their owners were expected to provide for them liberally so that they could start a new and independent life (Deut 15:12-18). As

28 Andrew D. Mayes, Deuteronomy (Edinburgh: Oliphants, 1979), 252.

29 Victor H. Matthews, The Hebrew Prophets and Their Social World: An Introduction (Ada: Baker Academic, 2012), 136-138. 
the Lord God's sacrificial love was bestowed upon the people of Israel in Egypt when they were weak and enslaved, the people were expected to deal with one another in like manner.

Unlike the Covenant Code, the uniqueness of the Deuteronomic Code is not just in its choice of words. For example, using the word "Hebrew" instead of "brother" (Deut 15:12) marks a radical change from the parallel law codes, especially the Covenant Code. Women are also given equal privilege with men in the release of slaves (Deut 15:12,17). These additions mark a significant step away from the Covenant Code. The Deuteronomic Code functioned differently from the Covenant Code by granting equal treatment to women. ${ }^{30}$ The treatment of equality shows clearly that the Deuteronomic Code springs from a society ${ }^{31}$ where the power of a father over his daughter was no longer supreme. ${ }^{32}$ Accordingly, those obliged to be freed are referred to as "brother" or "sister," implying that there is no room for "power over others." This humanitarian approach is missing in Exod 21:2-11. In Exodus, the female slave is given a lower status. According to Baker, ${ }^{33}$ a concubine is probably a slave. What is implicit in the Covenant Code becomes explicit in the Deuteronomic/Deuteronomistic Code. ${ }^{34}$

The act of selling a member of the Israelite community, in particular a woman, illustrates the importance of context with this hierarchal society (Deut 15:1-11). Nevertheless, the selling and maltreatment of women is not excusable.

The statement, "You shall let him go free" (Deut 15:12), which corresponds with the phrase, "Let my people go" (Exod 5:1), reveals a humanitarian approach. In Exodus, the command given is, "He shall go out free" (v.2), whereas in Deuteronomy, the owner was required to release his slave (Deut 15:18). ${ }^{35}$ In verses $13-14$ of Deut 15 , the owner is asked to provide the slave

30 Jeffrey H. Tigay, "The Significance of the End of Deuteronomy: Deuteronomy 34:10-12," Texts, Temples, and Traditions 1/2 (1996): 137-143 (148).

31 Women were part of the responsibility of the head of the household and fathers were responsible for the safety and fair treatment of their daughters. This shows that a man had power over a woman in the ANE society.

32 Samuel R. Driver, Deuteronomy: International Critical Commentary (New York: Charles Scribner's Sons, 1961), 182-183.

33 David L. Baker, Concubines and Conjugal Rights in Exodus 21:10 and Deuteronomy 21:14 (Wiesbaden: Harrassowitz Verlag, 2007), 1.

34 Meredith G. Kline, Treaty of the Great King: The Covenant Structure of Deuteronomy (Studies and Commentary; Grand Rapids: William B. Eerdmans, 1963), 90 .

35 Weinfeld, Deuteronomy 1-11, 282-283. 
with sheep (or goats), grain and wine in abundance. ${ }^{36}$ The understanding here is to bestow goods on the slave generously.

The Deuteronomic/Deuteronomistic Code goes beyond the provisions of Exod 21:2-11. The obligation aspect is missing in the Covenant Code. In the Covenant Code, the owner's responsibility towards the slave is highlighted. The slave must not begin his freedom in a state of destitution and insecurity but must rather enjoy full inclusion in society. The strong concern for the oppressed in this law can clearly be seen. The principle of love for God and for one's fellow man is vital to the covenant community and it is boldly demonstrated in this text whereas Exod 21:2-11 makes no provision for the released slaves. ${ }^{37}$

In the command to free indentured servants, "Therefore, I command you this word today" (Deut 15:15), the word "today" is noteworthy. It is placed exactly at the centre of the literary unit (between two sub-units: vv. 12-15a and 16-18). Here, the call to remember is not merely a way to evoke sympathy or compassion for the slave, which would lead to generosity, but rather to acknowledge their past, when they themselves were slaves in Egypt (Deut 5:15; $16: 12 ; 24: 18,22)$. The freedom from bondage in Egypt was not achieved on merit but rather because of God's love for the Israelites. The love of God is shown both in their deliverance from the tyranny of Egypt and also by providing ample support (cf. Exod 3:21-22 ["you will not go empty-handed"]; 11:2; 12:25-27). ${ }^{38}$ In return, the people should do no less to the manumitted slaves in the seventh year. ${ }^{39}$ A powerful motivating force is thus indicated. God's concern for the poor is revealed when this passage is compared with other codes. In Exodus, injustice is observed especially towards the female slave. ${ }^{40}$ The liberation of the male and the female slaves is not seen as an equal act of love but in Exodus, it is an act of cruelty. Total justice is seen when a person is set free and has some hope of success. ${ }^{41}$ If success is not achieved, their fate would be further slavery.

36 David P. Wright, Inventing God's Law: How the Covenant Code of the Bible Used and Revised the Laws of Hammurabi (Oxford: University Press, 2009), 192-193.

37 Wright, Inventing God's Law, 192.

38 Cf. Merrill, Deuteronomy, 245-246.

39 Niels P. Lemche, "The "Hebrew Slave": Comments on the Slave Law Ex. XXI 211," Vetus Testamentum 25/2 (1975): 137.

40 See Gregory Chirichigno, Debt-slavery in Israel and the Ancient Near East (The Library of Hebrew of Bible/Old Testament Series 141; Sheffield: A\&C Black, 1993), 342-342.

41 See Adrian, Schenker, "The Biblical Legislation on the Release of Slaves: The Road from Exodus to Leviticus," Journal for the Study of the Old Testament 23 (1998/78): 27. 
The law demands that freedom be given to all but if a slave, in spite of receiving freedom, decides to stay with the owner, he or she shall be categorised as a perpetual slave (Deut 15:16-17). The regulation and exhortation contained in vv.12-17 are applied equally to male and female slaves (v.17b), although they are totally missing in Exod 21. In the Exodus passage, the slaves are brought to God ("household gods before whom the ceremony was performed"), ${ }^{42}$ while Deuteronomy does not mention this. The reason for this is that such gods had been rendered illegal under Josiah's reform (2 Kgs $23: 24) .{ }^{43}$

Had the slaves given free service for six years, there would have been every indication of selfishness and greed on the part of the owner. Accordingly, the law indicates that the six years of service are worth the wages of a hired labourer. ${ }^{44}$ The slaves had worked for no pay and the wages that would have been paid to an employee for the same labour were to be considered full repayment for the debt that had caused the slavery in the first place. ${ }^{45}$ The law again cautions the owner, under whom the slaves serve because of their debt, not to consider it a hardship to free their slaves but rather they should free their slaves with total willingness. The result is a blessing from God. This concept is totally absent in the Exodus passage.

The reason for this discrepancy in Deuteronomy and Exodus is that the scene relates to the core law in Exodus and reviews it in a more acceptable light. This is not a bad thing per se because Israel's image as individuals as well as the corporate image of Israel as a whole is important to consider. Therefore, instead of a Hebrew slave that the master must free, he is seen as a Hebrew brother, working for a fellow countryman,

who is freed and compensated upon release, presumably so that he will not find himself immediately in straits and once again enslaved. This must be done because God blessed the master and freed the Israelites from Egyptian bondage, a major theme of Deuteronomy. ${ }^{46}$

It was assumed that the law of slavery in Deuteronomy was sound at that time, both theologically and economically. The economic feasibility of having a

42 See Anthony Phillips, "The Laws of Slavery: Exodus 21:2-11," Journal for the Study of the Old Testament 9/30 (1984): 1.

43 Cf. John H. Walton, Ancient Near Eastern Thought and the Old Testament: Introducing the Conceptual World of the Hebrew Bible (Grand Rapids: Baker Academic, 2006), 195.

44 See Brevard S. Childs, The Book of Exodus: A Critical, Theological Commentary (OTL; Louisville: Westminster John Knox Press, 1974), 14.

45 See Peter C. Craigie, The Book of Deuteronomy (The New International Commentary on the Old Testament; Grand Rapids: William B. Eerdmans, 1976), 239.

46 See Zev Fabber, The Hebrew Slave: Exodus, Leviticus and Deuteronomy [cited 10 April 2020]. Online: https://www.thetorah.com/article/the-hebrew-slave-exodusleviticus-and-deuteronomy. 
fresh start in life, that is, in the sense of historical and economic redemption (Exod 12:33-36), is given much emphasis. The law regards the slave as a person who has sold his or her service and not his or her own person. Unlike the case in Exodus, there is no mention in Deuteronomy of a hidden agenda of the owner to increase his wealth by giving the slave a wife and at the end of six years in order to retain the wife and children. The slave in the scribal political fiction has a voice in the community and, as a citizen, enjoys the same rights as his or her master. The slave not only has the right to freedom but may also live with his or her family. According to the Covenant Code, the slave must decide whether he or she wants freedom or family while in the Holiness Code, a slave's children can go with him or her but the freedom of the slave's wife is not mentioned. Justice and compassion for powerless members of the community are well addressed in this law.

\section{Deuteronomy 16:11-14}

Deuteronomy 16:1-17 presents the three feasts of Israel. Within the series of festivals, verses 1-8 (the Passover feast) are more elaborate, with verse 3 seemingly contradicting verse 8 . Scholars argue that the two feasts, "the Passover and the Feast of Unleavened Bread," have been combined (Mayes 1979:256). Deuteronomy 16 highlight the Passover with Unleavened Bread (vv.1-8), the Feast of Weeks (vv.9-12) and the Feast of Booths (vv.13-15), followed by a summary (vv.16-17). In celebrating these feasts, Yahweh expects his people to remember his faithfulness and to observe the feasts from generation to generation by involving "all members of the society" (vv.11, 14). This passage is a Deuteronomic/Deuteronomistic version, as it gives more importance to worship (the word "rejoice" is noteworthy in Deuteronomy). With the exception of the Passover, the three feasts have an agricultural setting and belong to the period of the settlement. ${ }^{47}$

The heart of the Passover festival is not merely to remember the salvific act of God and his blessing but also to have a fellowship meal involving "all members of the community," regardless of their socio-economic status. The law here motivates the head of the household to extend the celebration to servants and other people connected to his family. Deuteronomy 16:9-17 offers more detail about the Feast of Weeks and the Feast of Booths. The Deuteronomic/Deuteronomistic passage differs in one respect from the parallel passages in Exodus (23:14ff and 34:18ff) and Leviticus (23:15-22, 33-44); neither of the two feasts in Deuteronomy is connected with salvation history (cf. Exod 23:15; 34: 18; Lev 23:42-43). In the Leviticus, the dwelling in booths is designed to remind the people of Israel of their wandering in the desert while in exodus.

47 Hubert Cunliffe-Jones, Deuteronomy: Introduction and Commentary (London: SCM Press, 1951), 101. 
The striking significance of the Deuteronomic/Deuteronomistic Code lies not merely in Israel's history but rather also in the involvement of each member of the Israelite society ("Rejoice... you and your sons and your daughters, your male and female slaves, the Levites, the strangers, the orphans and widows" in vv.11 and 14). In the parallel passages, only men were given this status as they were deemed "true" members of the covenant community. For the Deuteronomist, not only men were afforded this privilege but everyone in the community, as the Israelites are reminded that they were once in a similar dependent position ${ }^{48}$ (cf. 15:15). Deuteronomy 16:12 states the reason for such a stipulation: "Remember that you were a slave in Egypt." In Deuteronomy, the reason for celebration is not merely to know how they escaped slavery but indeed also to recall their experience of servitude in Egypt (Exod 23:14; Lev 23:43; Deut 16:12). ${ }^{49}$ In Egypt, they all faced the same hardships and received deliverance. In the same way, each member of society should participate in the feast and each had access and rights to enjoy the feast. The festivals were a time of rejoicing for all members of the community. The Deuteronomist creates empathy for the weak and marginalised and lets them know that they too are to be given rest from labour to celebrate the redemptive act of God. Unlike the other codes, the celebration of the Passover gives new meaning to the community, emphasising the significance of each member, irrespective of their social standing or gender. This change is vital as it brings social bonding and renewal as well as a deep conviction that all Israelites are part of the community of God.

\section{E WOMEN AS PROPERTY}

Societal attitudes towards women in the Deuteronomic/Deuteronomistic Code are similar to those found in its legislative framework in the Covenant Code. An excellent case to prove this is found in the tenth commandment (Exod 20:17//Deut 5:21). In the Exodus text, women are included under the larger corpus, whereas Deuteronomy completely reverses the order: "Neither shall you covet your neighbour's wife; and you shall not desire your neighbour's house, his field, or his manservant, or his maidservant, his ox, or his ass, or anything that is your neighbour's." It seems that in Deuteronomy the wife comes first and is a class by herself; and only after that class comes the man's property. This observation does not excuse the disempowerment of women but it is important to note that the emphasis has changed. As Wright declares, "Deuteronomy interprets house as including only domestic property, so that the wife is not listed as one among other items in the household." 50

\footnotetext{
48 Cf. Merrill, Deuteronomy, 254.

49 See Mayes, Deuteronomy, 260.

50 Christopher J. Wright, The Message of Deuteronomy (Nottingham: Inter-Varsity Press, 2014), 368.
} 


\section{F WOMEN IN BONDAGE}

Noteworthy, the position of the slave woman in Deut $15: 12-18^{51}$ has markedly improved from that presented in Exod 21:2-11..$^{52}$ This is evident in the text of Exodus, where broad provisions are made for the release of the slave (v.2), while Deuteronomy contains an addition: "If your brother, Hebrew man, or a Hebrew woman ${ }^{53}$ is sold to you, he shall serve you six years, and in the seventh year you shall let him go free from you" (Deut 15:12). The difference here is that the law suggests that a female slave should receive the same treatment as a male slave, although in practice this was probably not the case.

The regulations regarding the wife and family of a slave in Exod 21:2-4 are disregarded in Deuteronomy. ${ }^{54}$ This means that by the time Deuteronomy was composed, slave concubines might have been less prevalent. Wright is convinced that this might be because of the Deuteronomist's philanthropic

51 "If any of your people - Hebrew men or women - sell themselves to you and serve you six years, in the seventh year you must let them go free. And when you release them, do not send them away empty-handed. Supply them liberally from your flock, your threshing floor and your wine press. Give to them as the Lord your God has blessed you. Remember that you were slaves in Egypt and the Lord your God redeemed you. That is why I give you this command today. But if your servant says to you, I do not want to leave you, because he loves you and your family and is well off with you, then take an awl and push it through his earlobe into the door, and he will become your servant for life. Do the same for your female servant. Do not consider it a hardship to set your servant free because their service to you these six years has been worth twice as much as that of a hired hand. And the Lord your God will bless you in everything you do."

52 "If you buy a Hebrew servant, he is to serve you for six years. But in the seventh year, he shall go free, without paying anything. If he comes alone, he is to go free alone; but if he has a wife when he comes, she is to go with him. If his master gives him a wife and she bear him sons or daughters, the woman and her children shall belong to her master, and only the man shall go free. But if the servant declares, I love my master and my wife and children and do not want to go free,' then his master must take him before the judges. He shall take him to the door or the doorpost and pierce his ear with an awl. Then he will be his servant for life. If a man sells his daughter as a servant, she is not to go free as male servants do. If she does not please the master who has selected her for himself, he must let her be redeemed. He has no right to sell her to foreigners because he has broken faith with her. If he selects her for his son, he must grant her the rights of a daughter. If he marries another woman, he must not deprive the first one of her food, clothing and marital rights. If he does not provide her with these three things, she is to go free, without any payment of money."

53 The emphasis here is to highlight how the patriarchal culture of the Hebrews did not appreciate not even the women in this context.

54 See Roland de Vaux, Ancient Israel. (Transl. John McHugh; N.Y: McGraw-Hill, 1961), 86. 
spirit $^{55}$ (Deut 15:13). ${ }^{56}$ Despite the suggestion of a philanthropic spirit, there is no evidence that the disempowerment of and violence against women had in any way ceased.

Although this "unprecedented" concern for the slave is based on Yahweh's treatment of the people of Israel when they were enslaved in Egypt, the "unprecedented" concern shows that Israel may have expressed second thoughts about the absolute control exerted by one person over another. ${ }^{57}$ However, the revolution against slavery in Israel was a slow progression and certainly the disempowered status of women did not change overnight.

\section{G WOMEN'S RIGHTS VIOLATED}

Female disempowerment is further evident in the attitudes of fathers towards their daughters. A father, it seems, could renounce his authority over his unbetrothed daughter by deciding that the man who seized her and lay with her had the right to marry her (Deut 22:28-29). The daughter's sexual rights were not even taken into consideration. ${ }^{58}$ Although in the Exodus context, the man was required to pay the mohar price, ${ }^{59}$ the father took away the daughter's right to choose by deciding on her behalf. This is a violation of women's right to be treated equally, even when Deuteronomy suggests that the seducer of the woman was forced to take her as his wife. The arrangement proves that a woman's rights shifted from the father to another man and not to the woman herself. ${ }^{60}$ The same attitude is displayed when an erring man was made to forfeit his right to divorce his wife for the rest of his life. In this instance, the woman fared better but the

55 See Driver, Deuteronomy, 183, who is not entirely persuaded by Wright's view when he says, "The slave is to be provided for generously out of the master's flocks and supplies, since the Lord provided liberally for Israel when he led her out of Egypt." 56 "Not to let him go empty handed" is the phrase this might be based on (Deut 15:13).

57 Wright, She Shall not Go Free, 430.

58 Cf. Driver, Deuteronomy, 83.

59 It is the price for a bride - an unspecified amount stated in Exod 22:16-17.

60 De Vaux, Ancient Israel, 36. 
disempowerment of women was still present in a society ${ }^{61}$ like Israel where female divorcees ${ }^{62}$ had no rights socially or economically. ${ }^{63}$

Some laws in Deuteronomy even deferred the right of young girls to decide to keep their virginity or not. ${ }^{64}$ These include the following:

When you go to war against your enemies and the Lord your God delivers them into your hands and you take captives, if you notice among the captives a beautiful woman and are attracted to her, you may take her as your wife. Bring her into your home and have her shave her head, trim her nails and put aside the clothes she was wearing when captured. After she has lived in your house and mourned her father and mother for a full month, then you may go to her and be her husband and she shall be your wife. If you are not pleased with her, let her go wherever she wishes. You must not sell her or treat her as a slave, since you have dishonoured her (Deut 21:10-14).

The passage above shows that women who were taken captive could be treated as though their sexual rights ${ }^{65}$ had nothing to do with human dignity, thus, increasing the negative treatment of women in general. Furthermore, according to Driver, ${ }^{66}$ such treatment is an act of a "violent and primitive-minded people." Such is also the case in Deut 22:13-21:

If a man takes a wife and, after sleeping with her, dislikes her and slanders her and gives her a bad name, saying, I married this woman, but when I approached her, I did not find proof of her virginity,' then

61 See a list of scholars, including Claude Schaeffer, Jean Nougayrol and Eleanor Amico, who postulate that "the position of women in Syro-Palestine, especially Ugarit, was better than the position of women in Mesopotamia. In Syro-Palestine itself, the position of women in Ugarit was portrayed as better than the position of women in Ancient Israel." The observation is an indictment of Israel because it creates the impression that in a polytheistic society like Ugarit, women were more favoured in society where monotheism took priority. Cf. Marsman, Women in Ugarit and Israel, 35 .

62 Marsman, Women in Ugarit and Israel, 34-35.

63 Cf. Mark E. Biddle, Deuteronomy (Macon: Smyth \& Helwys, 2003), 225.

${ }^{64}$ Immanuel Lewy, The Growth of the Pentateuch (New York: Bookman Association, 1955), 95.

65 The custom of looking for virginity in a newly married woman was a practice of primitive-minded people - if she did not possess sexual purity, she was stoned for having wrought folly in Israel. The phrase "folly in Israel" implies the sense of a national ideal or national conscience that is indicative of violence towards and disempowerment of women. Cf. George A. Smith, Deuteronomy (Cambridge: Cambridge University Press, 1950), 263.

66 Driver, Deuteronomy, 255. 
the young woman's father and mother shall bring to the town elders at the gate proof that she was a virgin. Her father will say to the elders, I gave my daughter in marriage to this man, but he dislikes her. Now he has slandered her and said, I did not find your daughter to be a virgin." But here is the proof of my daughter's virginity.' Then her parents shall display the cloth before the elders of the town, and the elders shall take the man and punish him. They shall fine him a hundred shekels of silver and give them to the young woman's father because this man has given an Israelite virgin a bad name. She shall continue to be his wife; he must not divorce her as long as he lives. If, however, the charge is true and no proof of the young woman's virginity can be found, she shall be brought to the door of her father's house and there the men of her town shall stone her to death. She has done an outrageous thing in Israel by being promiscuous while still in her father's house. You must purge the evil from among you.

According to Smith, this kind of practice is also found in Semitic customs, to which Hebrews added their own interpretation. ${ }^{67}$ Whether Smith's finding is true or not, it is clear that Israelite society was characterised as hostile to female empowerment.

Another peculiar law in the Deuteronomistic Code is found in Deut 22:23-27,

If there is a betrothed virgin, and a man meets her in the city and lies with her, then you shall bring them both out to the gate of that city, and you shall stone them to death with stones, the young woman because she did not cry for help though she was in the city, and the man because he violated his neighbor's wife. So, you shall purge the evil from your midst. "But if in the open country a man meets a young woman who is betrothed, and the man seizes her and lies with her, then only the man who lay with her shall die. But you shall do nothing to the young woman; she has committed no offense punishable by death. For this case is like that of a man attacking and murdering his neighbor, because he met her in the open country, and though the betrothed young woman cried for help there was no one to rescue her.

Nonetheless, the story illustrates how society was ordered hierarchically to determine how women were treated. For example, if a man were to seduce a betrothed virgin in the city (vv. 23-24), both the man and the woman would be stoned. However, if a man were to seduce a betrothed virgin in the open country where there were no witnesses, only the man would be stoned. ${ }^{68}$ The reason

67 See Smith, Deuteronomy, 263.

68 Cf. Ibid., 267. 
given for this is that if the woman cried for help, there was no one ${ }^{69}$ to rescue her (v.27).

Based on these textual examples, it is evident that women were treated unequally as men. A woman's position and liberation were not considered important in ancient Israel. The aforementioned texts in Deuteronomy demonstrate the extent to which women were oppressed and exploited. It is reasonable to conclude that women were disempowered and violated due to the patriarchal nature of Israelite society.

\section{H WOMEN AND DIVORCE}

In the legislation of Deut 21:10-14, women are also treated differently, especially when it comes to divorce. It is remarkable however that even when a woman takes a month to herself before her captor in war "may go into her and be her husband" (v.13), she remains at the mercy of the captor's family and their "primitive" disempowering environment. ${ }^{70}$ Furthermore, if ${ }^{71}$ the husband is happy after he has taken her sexual rights from her, he may not treat her as a slave nor may he sell her for money. This law in Deuteronomy supported the enactment of captive marriages in Israel and it failed to benefit women neither did it protect women from victimisation. ${ }^{72}$ It certainly authorised the husband to bring about disempowerment and violence against her if he was displeased with her. Thus, her legal marital status was based on nothing else but pure chance. Deuteronomy 24:1-4 explains the consequences of divorce, which is only ascribed to insubstantial household displeasures. ${ }^{73}$ However, the man may still find "some indecency in her."74 The law suggests that when it came to women and their marital rights, only the authoritative figures in the family and society were important. Those authoritative figures were men.

The last law to be considered in Deuteronomy is in 24:5, which is analogous to $20: 5-7 .{ }^{75}$ It states that, "When a man is newly married, he shall not go out with the army or be charged with any business; he shall be free at home

69 The open country may have been wild and probably in its earlier sense was uncultivated and therefore uninhabited. See Ibid., 268.

70 Driver, Deuteronomy, 245.

71 My emphasis here is based on the husband's rights at the expense of the wife's rights.

72 Cf. Ephraim Neufeld, Ancient Hebrew Marriage Laws (London: Longmans Green, 1944), 78.

73 There may be a wide range of interpretations here but I support the view that the "rigorist school of Hillel is in agreement that any reason, however trivial, such as the charge that a wife had cooked a dish badly, or merely that the husband preferred another woman, was good enough for a divorce." However, the Shammai School of rabbis claim that only adultery and misconduct were grounds for divorce.

74 De Vaux, Ancient Israel, 34.

75 Cf. Driver, Deuteronomy, 273. 
one year, to be happy with his wife whom he has taken" (Deut 24:5). This law may have been an attempt to stabilise marriage by safeguarding what is usually the most difficult period of adjustment in the marriage of a young couple. However, only the husband is allowed some kind of dispensation, while the wife is not. She is required to avail herself to strengthen their marriage without due consideration for her needs, which would result in subservience and dependency on her husband.

\section{CONCLUSION}

In this article, it was argued that Deuteronomic/Deuteronomistic laws and, to some extent, the interrelated the Covenant Code show how the social structures of ancient Israel helped to maintain an imbalance of rights of women in society, especially in terms of women's lack of access to society's wealth as they had no property rights of their own or other socio-economic benefits. The subordination of women in Deuteronomy has been explored from the following perspectives: their role and image, their status in society and family structures and the limited contributions of women in these spheres including the fact that female slaves were ruled with an iron hand and unequal might. A reading framework from a social-scientific feminist point of view was employed to analyse and critique how the disempowerment of women in ancient Israel was formed and how it has unfolded in light of the current global situation of the negative treatment of women. This deconstruction of the ancient Israelite culture in the Deuteronomistic Code recognises that the current global context is vastly different from that of Israel, which, at that time, was a very patrilineal and patriarchal society. ${ }^{76}$ However, the reconstruction or re-interpretation of Deuteronomy is an attempt to show how the revisions of this book could help to address 21 st century laws and the contemporary feminist reader in understanding strong equal human rights in a context such as South Africa as well as the rest of the world. Thus, such a reading of Deuteronomy could help "women to move from being passive and weak, to being strong, thereby turning female experiences into spaces of value, honour and empowerment," 77 across various social and economic spheres of life. ${ }^{78}$

\section{J BIBLIOGRAPHY}

Baker, David L. Concubines and Conjugal Rights in Exodus 21:10 and Deuteronomy 21:14. Wiesbaden: Harrassowitz Verlag, 2007.

Barton, J. Ethics in Ancient Israel. Oxford: OUP, 2014.

Biddle, Mark E. Deuteronomy. Macon: Smyth \& Helwys, 2003.

Bosman, Hendrik J. Ludolph. "Such a Thing Is not Done in Israel: The Judicial System of Ancient Israel." Pages 190-205 in Plutocrats and Paupers: Wealth and

\footnotetext{
76 Cf. Matthews and Benjamin, Social World of Ancient Israel, 8.

77 Christina Landman, "Healing the Wounded," OTE 33/3 (2020): 673.

78 John Barton, Ethics in Ancient Israel (Oxford: OUP, 2014), 25.
} 
Poverty in the Old Testament. Edited by H. L. Bosman, I.G.P. Gous and I.J.J. Spangenberg. Pretoria: J.L. van Schaik, 1996.

Brueggemann, Walter. Deuteronomy. Nashville: Abingdon Press, 2001.

Childs, Brevard S. The Book of Exodus: A Critical, Theological Commentary. OTL. Louisville: Westminster John Knox Press, 1974.

Chirichigno, Gregory. Debt-slavery in Israel and the Ancient Near East. The Library of Hebrew of Bible/Old Testament Series 141. Sheffield: A\&C Black, 1993.

Claassens, L. Juliana, Sa'diyya Shaikh and Leslie Swartz. "Engaging Disability and Religion in the Global South." Pages 147-164 in The Palgrave Handbook of Disability and Citizenship in the Global South. Cham: Palgrave Macmillan, 2019.

Craigie, Peter C. The Book of Deuteronomy. The New International Commentary on the Old Testament. Grand Rapids: William B. Eerdmans, 1976.

Crüsermann, Frank. The Torah: Theology and Social History of Old Testament Law. Minneapolis: Fortress Press, 1996.

Cunliffe-Jones, Hubert. Deuteronomy: Introduction and Commentary. London: SCM Press, 1951.

De Vaux, Roland. Ancient Israel. Translated by John McHugh. New York: McGrawHill, 1961.

Driver, Samuel R. Deuteronomy. International Critical Commentary. New York: Charles Scribner's Sons, 1961.

Esler, Philip Francis. Ancient Israel: The Old Testament in Its Social Context. Fortress Press, 2006.

Fabber, Zev. The Hebrew Slave: Exodus, Leviticus, and Deuteronomy. Cited 10 April 2020. Online: https://www.thetorah.com/article/the-hebrew-slave-exodusleviticus-and-deuteronomy. 5 October 2013.

Kline, Meredith G. Treaty of the Great King: The Covenant Structure of Deuteronomy. Studies and Commentary. Grand Rapids: William B. Eerdmans, 1963.

Landman, Christina. "Healing the Wounded." Old Testament Essays 33/3 (2020): 663 673.

Lemche, Niels Peter. "The "Hebrew Slave": Comments on the Slave Law Ex. XXI 211." Vetus Testamentum 25/2 (1975): 129-144.

Le Roux, Jurie. "Pro Pent. A Project for the Study of the Pentateuch in South Africa." Pages 1-21 in A Critical Study of the Pentateuch: An Encounter between Europe and Africa. Edited by Eckhart Otto and Jurie LeRoux. Münster: Lit Verlag. 2005. "We Are Shaped by Past Interpretations." Verbum et Ecclesia 40/1 (2019): 1-9.

Lewy, Immanuel. The Growth of the Pentateuch. New York: Bookman Association, 1955.

Marsman, Hennie J. Women in Ugarit and Israel: Their Social and Religious Position in the Context of the Ancient Near East. Leiden: Brill, 2003.

Matthews, Victor H. The Hebrew Prophets and Their Social World: An Introduction. Ada: Baker Academic, 2012.

Matthews, Victor H. and Don C. Benjamin. Social World of Ancient Israel: 1250-587 BCE. Peabody: Hendrickson, 1993.

Mayes, Andrew D.H. Deuteronomy. Edinburgh: Oliphants, 1979.

Merrill, Eugene H. "Deuteronomy." An Exegetical and Theological Exposition 1/4 (1994): 1-50.

Meyers, Carol L. Exodus. Cambridge: University Press, 2005. 
"Was Ancient Israel a Patriarchal Society?" Journal of Biblical Literature 133/1 (2014): 8-27.

Neufeld, Ephraim. Ancient Hebrew Marriage Laws. London: Longmans Green, 1944.

Otto, Eckhart. Das Deuteronomium in Pentateuch und Hexateuch: Studien zur Literaturgeschichte von Pentateuch und Hexateuch im Lichte des Deuteronomiumrahmens. Tubingen: JCB Mohr-Paul Siebeck, 2000.

Religion Past \& Present: Encyclopaedia of theology and Religion. Leiden: Brill, 2011.

Deuteronomium 1-11: Herders theologischer Kommentar zum Alten Testament. Herder, Germany: Freiburg, 2012.

Park, Esther H. "Women in Exodus and Asian Immigrant Women: Asian Female Immigrants' Bible Reading Strategy on Exodus 1-4." T\&T Clark Handbook of Asian American Biblical Hermeneutics (2019): 220.

Phillips, Anthony. "The Laws of Slavery: Exodus 21.2-11." Journal for the Study of the Old Testament 9/30 (1984): 51-66.

Pietersen, Doniwen and Dirk J. Human. "YHWH's Mouthpiece to the Exiles." Stellenbosch Theological Journal 7/1 (2021): 1-24.

Rabens, Volker. "The Bible and Ethics: Pathways for Dialogue." In die Skriflig 51/3 (2017): 1-12.

Schenker, Adrian. "The Biblical Legislation on the Release of Slaves: The Road from Exodus to Leviticus." Journal for the Study of the Old Testament 23/78 (1998): 23-41.

Schipper, Bern U. "Egypt and the Kingdom of Judah under Josiah and Jehoiakim." TEL AVIV 37/1 (2010): 200-226.

Ska, Jean-Louis. Introduction to Reading the Pentateuch. Winona Lake: Eisenbrauns, 2006.

Smith, George A. Deuteronomy. 1st edition. Cambridge: Cambridge University Press, 1950.

Sneed, Mark. "Social Scientific Approach to the Hebrew Bible." Religion Compass 2/3(2008): 287-300.

Snyman, Fanie. "A Theological Appraisal of the Book of Malachi." Old Testament Essays 27/2 (2014): 597-611.

Tigay, Jeffrey H. "The Significance of the End of Deuteronomy: Deuteronomy 34:10 12." Texts, Temples, and Traditions 1/2 (1996): 137-143.

Van der Toorn, Karen. Family Religion in Babylonia, Syria and Israel: Continuity and Change in the Forms of Religious Life. Studies in the History and Culture of the Ancient Near East VII. Leiden: Brill, 1996.

Walton, H. John and H. Victor Matthews. Genesis - Deuteronomy. The IVP Bible Background Commentary. Downers Grove: InterVarsity Press, 1997. Ancient Near Eastern Thought and the Old Testament: Introducing the Conceptual World of the Hebrew Bible. Grand Rapids: Baker Academic, 2006.

Weinfeld, Moshe. Deuteronomy 1-11. The Anchor Bible Volume 5. New York: Doubleday, 1995.

Wright, Christopher J. The Message of Deuteronomy. Nottingham: Inter-Varsity Press, 2014.

Wright, David P. Inventing God's Law: How the Covenant Code of the Bible Used and Revised the Laws of Hammurabi. Oxford: University Press, 2009. 
. “'She Shall not Go Free as Male Slaves Do': Developing Views about Slavery and Gender in the Laws of the Hebrew Bible." Pages 125-142 in Beyond Slavery. Edited by Bernadette Brooten. New York: Palgrave Macmillan, 2010.

Doniwen Pietersen is Research Associate in Old Testament Studies in the Department of Old Testament and Hebrew Scriptures, Faculty of Theology and Religion, University of Pretoria. Email: doniwen.pietersen@gmail.com ORCID ID: https://orcid.org/0000$\underline{0002-3050-589 X}$ 